\title{
Screening of Korean medicinal plants for possible osteoclastogenesis effects in vitro
}

\author{
Yu Na Youn · Erang Lim • Nari Lee \\ Young Seop Kim · Min Seon Koo · Soon Young Choi
}

Published online: 16 November 2007

(C) Springer-Verlag 2007

\begin{abstract}
Bone undergoes continuous remodeling through bone formation and resorption, and maintaining the balance for skeletal rigidity. Bone resorption and loss are generally attributed to osteoclasts. Differentiation of osteoclasts is regulated by receptor activator of nuclear factor NF- $k$ B ligand (RANKL), a member of tumor necrosis factor family. When the balance is disturbed, pathological bone abnormality ensues. Through the screening of traditional Korean medicinal plants, the effective molecules for inhibition and stimulation of RANKL-induced osteoclast differentiation in mouse bone marrow macrophages were identified. Among 222 methanol extracts, of medicinal plants, 10 samples exhibited ability to induce osteoclast differentiation. These include Dryobalanops aromatica, Euphoria longana, Lithospermum erythrorhizon, Prunus mume, Prunus nakaii, and Polygonatum odoratum. In contrast, Ailanthus altissima, Curcuma longa, Solanum nigrum, Taraxacum platycarpa, Trichosanthes kirilowii, and Daphne genkwa showed inhibitory effects in RANKLinduced osteoclast differentiation.
\end{abstract}

Keywords Bone $\cdot$ Medicinal plants $\cdot$ Osteoclast . Osteoclastogenesis · TRAP assay

Y. N. Youn · E. Lim · S. Y. Choi $(\bowtie)$

Department of Biology, Sookmyung Women's University, Seoul 140-742, Republic of Korea

e-mail: sychoi@sm.ac.kr

\section{Y. S. Kim}

Korea Research Institute of Chemical Technology,

Daejeon 305-600, Republic of Korea

N. Lee $\cdot$ M. S. Koo

Korea Food Research Institute, Songnam,

Kyeongki-do 463-746, Republic of Korea

\section{Introduction}

Bone destruction is observed in advanced cases of rheumatoid arthritis and the neoplastic diseases, osteoporosis, and periodontitis. The balance between bone formation and resorption is tightly regulated by osteoblast and osteoclast, respectively, to maintain the homeostasis of our skeleton. Osteoclasts are sole bone-resorptive multinucleated cells (MNCs) that derived from hematopoietic cells. Excessive osteoclastogenesis or activation of mature osteoclasts causes the bone destruction which is implicated in rheumatoid arthritis, osteoporosis, multiple myeloma and bone metastasis.

Bone mineral density (BMD) and bone metabolism are affected by genetic, endocrine, mechanical and nutritional factors, with interactions among the different factors [1]. Bone mass in adult humans decreases with age, leading to an increased risk of fractures. Osteoporosis occurs frequently in postmenopausal women due to decrease in estrogen levels. Despite its positive effects on the bone physiology, estrogen replacement therapy is no longer recommended as the first choice therapy for the prevention and treatment of the postmenopausal osteoporosis because it increases the risks of cardiovascular, thromboembolic, and breast cancer [2]. As an alternative way to the hormone therapy, the use of phytoestrogens has attracted attention [3]. Nutritional factors are of particular importance to bone health because they are modifiable [4].

Treating perimenopausal and postmenopausal women with $40 \mathrm{~g} /$ day soy protein isolate providing $80-90 \mathrm{mg} / \mathrm{day}$ of isoflavones attenuated the loss of bone mineral density in the spine but not in other sites [5-8]. Onion and mixtures of vegetables, salads and herbs inhibit the bone resorption when metabolic acid is completely buffered with potassium 
citrate $[9,10]$. Sage, rosemary and thyme, which are the herbs rich in essential oil, also strongly inhibit bone resorption. There is a long history in the use of essential oils as medical applications for the relief of head and chest colds as well as pain [10]. Natural products of plant origin are still a major part of traditional medicinal systems in Korea. Korean herbal formulations, such as Yukmi-jihangtang and Dae-bo-won-chun, were reported for their preventive effect on the progress of bone loss in the rats $[11,12]$.

To examine the inhibitory effects of Korean traditional medicinal plant extracts on the bone resorption in the mouse macrophage cells, we have screened the inhibitory activities. Here, we report that the methanol extracts of Ailanthus ltissima, Curcuma longa, Solanum nigrum, Taraxacum platycarpa, Trichosanthes kirilowii and Daphne genkwa inhibit osteoclastogenesis.

\section{Materials and methods}

\section{Reagents}

The methanol extract was of medicinal plants provided by Dr. Young Seop Kim (Korea Research Institute of Chemical Technology, South Korea). Minimal essential medium alpha modification ( $\alpha$-MEM), fetal bovine serum (FBS), and antibiotics were purchased from Well Gene (Dae gu, South Korea). Macrophage colony stimulation factor(M-CSF) were purchased from R\&D Systems. TRANCE was provided by Dr. Lee (University of Ewha Women's University, Korea). TRAP staining kit (Leukocyte acid phosphatase kit) was obtained from Sigma (St. Louis, Miss., USA).

Culture of mouse bone marrow mononuclear cells

The bone marrow cells were isolated from the long bones of 4-week-old C57BL/6 male mice, and cultured with $\alpha$-MEM/ $10 \% \mathrm{FBS} / 1 \%$ antibiotics with M-CSF $(25 \mathrm{ng} / \mathrm{ml})$ in a humidified incubator $\left(5 \% \mathrm{CO}_{2}\right.$ in air) at $37^{\circ} \mathrm{C}$. After $24 \mathrm{~h}$ of cultures, the non-adherent cells were collected and centrifuged to obtain the bone marrow macrophage (BMM) cells which were the depleted stromal cells. For the osteoclast differentiation experiments, the BMM cells were cultured in 96-well plates $\left(3 \times 10^{4} /\right.$ well $)$ with M-CSF $(50 \mathrm{ng} / \mathrm{ml})$, TRANCE (400 ng/ml) and stimuli for 6-9 days.

Tartrate-resistant acid phosphatase (TRAP) assay

To determine the characteristics of osteoclast differentiation, cells were fixed with $3.7 \%$ formaldehyde for $10 \mathrm{~min}$ and then washed with distilled water. Then the cells were stained for TRAP with $0.1 \mathrm{M}$ acetate solution containing $6.76 \mathrm{mM}$ sodium tartrate, $0.12 \mathrm{mg} / \mathrm{ml}$ naphthol AS-MX phosphate, and $0.07 \mathrm{mg} / \mathrm{ml}$ of fast Garnet GBC solution as described in the manufacturer's instructions (Leukocyte acid phosphatase kit) for $30 \mathrm{~min}$ at room temperature.

\section{Results and discussion}

The screening of 222 specimens of Korean traditional medicinal plants for possible tartrate-resistant acid phosphatase inhibitory and stimulatory effects was performed (Table 1). The methanol extracts of Dryobalanops aromatica, Euphoria longana, Lithospermum erythrorhizon, Prunus mume, Prunus nakaii, Polygonatum odoratum, Alpinia oxyphylla, and Sambucus williamsii var.coreana showed stimulatory effects for osteoclast differentiation by TRAP assay (Fig. 1b; Table 2). However, Ailanthus altissima, Curcuma longa, Solanum nigrum, Taraxacum platycarpa, Trichosanthes kirilowii, Daphne genkwa, Gleditsia japonica, Picrasma quassioides, Sanguisorba officinalis, Citrus aurantium, Cnidium officinale, Lindera strychnifolia, Melandrium firmum, Phaseolus angularis, Rheum undulatum and Taraxacum platycarpa suppressed the osteoclastogenesis (Fig. 1c; Table 3).

The positive effects of nutritional supplement with herbal formulation extracts on bone mineral density and height in prepubescent children were reported [13].

The methanol extract and its major bioactive compound, gallic acid of Orostachys japonicus, greatly enhanced the activities of hepatic alcohol dehydrogenase, the microsomal ethanol-oxidizing enzyme, and aldehyde dehydrogenase in a dose dependent manner [14]. In additions, the inhibitory effects on the formation of carcinogenic $N$-nitrosodimethylamine were observed [15].

The main root of Aconitum carmichaelli has been used in Chinese herbal medications mainly for the treatment of musculoskeletal disorders, and the herbal formulations containing it have been used for the treatment of rheumatism and heart failure as well as improvement of the immune system and retarding aging [16, 17]. The plant contained the highly toxic C19 diterpenoid alkaloids of aconitine, mesaconitine and hypaconitine. A. altissima (synonym A. glandulosa) has been used to treat cold, gastric diseases, and cancer. From the bioassay-oriented study, it is reported that it has cytotoxicity and antiproliferative activities. It contains quassinoids, indole and $\beta$-carboline alkaloids. These compounds are reported for antitubercular, antimalarial, and inhibitory effects against Epstein-Barr virus [18]. Furthermore, other Ailanthus species have anti-cancer agents [18]. Curcuma longa has been in use for centuries as a dye and also as a component 
Table 1 Korean medicinal plants for possible osteoclastogenesis in this experiment

\begin{tabular}{|c|c|c|c|c|}
\hline Body & Flower & Seed & Root & Other \\
\hline Agrimonia pilosa & Althaea rosea & Allium tuberosum & Aconitum carmichaeli & Boswellia carterii \\
\hline Akebia quinata & $\begin{array}{l}\text { Chrysanthemum } \\
\text { indicum }\end{array}$ & Alpinia katsumadai & Aconitum ciliare & Dryobalanops aromatica \\
\hline Albizzia julibrissin & Daphne genkwa & Alpinia oxyphylla & Aconitum koreanum & Flammulina velutipes \\
\hline Artemisia apiace & Eugenia caryophyllata & Amomum tsao-ko & Aconium carmichaeli & Ganoderma lucidum \\
\hline Artemisia asiatica & Lonicera japonica & Arctium lappa & Acyranthes japonica & Lygodium japonica \\
\hline Artemisia capillaris & Pinus densiflora & $\begin{array}{l}\text { Brassica chinensis } \\
\text { var.oleifera }\end{array}$ & Adenophora remotiflorus & Lyophyllum ulmarium \\
\hline Biota orientalis & Pueraria thunbergiana & Brassica juncea & Adenophora triphylla & $\begin{array}{l}\text { Phyllostachys } \\
\text { bambusoides }\end{array}$ \\
\hline Cassia angustifolia & Tussilago farfar & Broussonetia kazinoki & Ailanthus altissima & $\begin{array}{l}\text { Phyllostachys nigra } \\
\text { var.henonis }\end{array}$ \\
\hline Cephalonoplos segetum & Typha orientalis & Cannabis sativa & Alisma orientale & Pinus densiflora \\
\hline Chelidonium majus & Zea mays & Capsicum anпиит & Allium macrostemon & Pleurotus eryngii \\
\hline Chrysanthemum sibiricum & & Carpesium abrotanoides & Alpinia officinarum & Polyporus umbellatus \\
\hline Cinnamoтит cassia & & Carthamus tinctorius & Anemarrhena asphodeloides & Poria cocos \\
\hline Circium japonicum & & Cassia tora & Anthriscus sylvestris & \\
\hline Eclipta prostrata & & Celosia argentea & Arisaema amurense & \\
\hline Elsholtzia ciliata & & Castanea crenata & Aristolochia cordata & \\
\hline Epimedium koreanum & & Citrus aurantium & Asiasarum sieboldi & \\
\hline Equisetum hiemale & & Citrus unshiu & Asparagus cochinchinensis & \\
\hline Eriocaulon sieboldianum & & Coix lachryma-jobi & Aster tataricus & \\
\hline Eugenia aromatica & & Croton tiglium & Atractylodes japonica & \\
\hline Gallus domesticus & & Cucumis melo & Bretilla striata & \\
\hline Geranium thunbergii & & Cuscusta chinensis & Caragana sinica & \\
\hline Ginkgo biloba & & Dianthus chinensis & Cistanche deserticola & \\
\hline Gleditsia japonica & & Draba nemorosa & Clematis mandshurica & \\
\hline Houttuynia cordata & & Euphorbia lathyris & Cnidium officinale & \\
\hline Kalopanax pictus & & Euphoria longana & Cocculus trilobus & \\
\hline Lonicera japonica & & Euryale ferox & Codonopsis pilosula & \\
\hline Lophatherum gracile & & Evodia officinalis & Coptis japonica & \\
\hline Loranthus parasiticus & & Foeniculum vulgare & Cremastra variabilis & \\
\hline Lycopus coreanus & & Gardenia jasminoides & Curcuma longa & \\
\hline Melandrium firmum & & Gleditsia japonica & Cynanchum wilfordii & \\
\hline $\begin{array}{c}\text { Melia azedarach } \\
\text { var.japonica }\end{array}$ & & Glycine $\max$ & Cyperus rotundus & \\
\hline Mucuna birdwoodiana & & Gossypium nanking & Dalbergia odorifera & \\
\hline Nelumbo nucifera & & Hordeum vulgare & Dioscorea japonica & \\
\hline Nepeta japonica & & Hovenia dulcis & Drynaria fortunei & \\
\hline Orostachys japonicus & & Juglans sinensis & Erucibe obtusifolia & \\
\hline Persicaria tinctoria & & Kochia scoparia & Dryopteris crassirhizoma & \\
\hline Phyllostachys nigra & & Luffa cylindrical & Euphorbia kansui & \\
\hline Polygonum aviculare & & Lycium chinense & Euphorbia pekinensis & \\
\hline Portulaca oleracea & & Lycopodium clavatum & Gastrodia elata & \\
\hline Pterocarpus santalinus & & Phaseolus angularis & Gentiana macrophylla & \\
\hline Rhus verniciflua & & Phaseolus radiatus & Gentiana scabra & \\
\hline $\begin{array}{l}\text { Sambucus williamsii } \\
\text { var.coreana }\end{array}$ & & Pinus koraiensis & Glycyrrhiza glabra & \\
\hline Sargassum fusiforme & & Piper longum & Isatis tinctoria & \\
\hline Saururus chinensis & & Piper nigrum & Laminaria japonica & \\
\hline
\end{tabular}


Table 1 continued

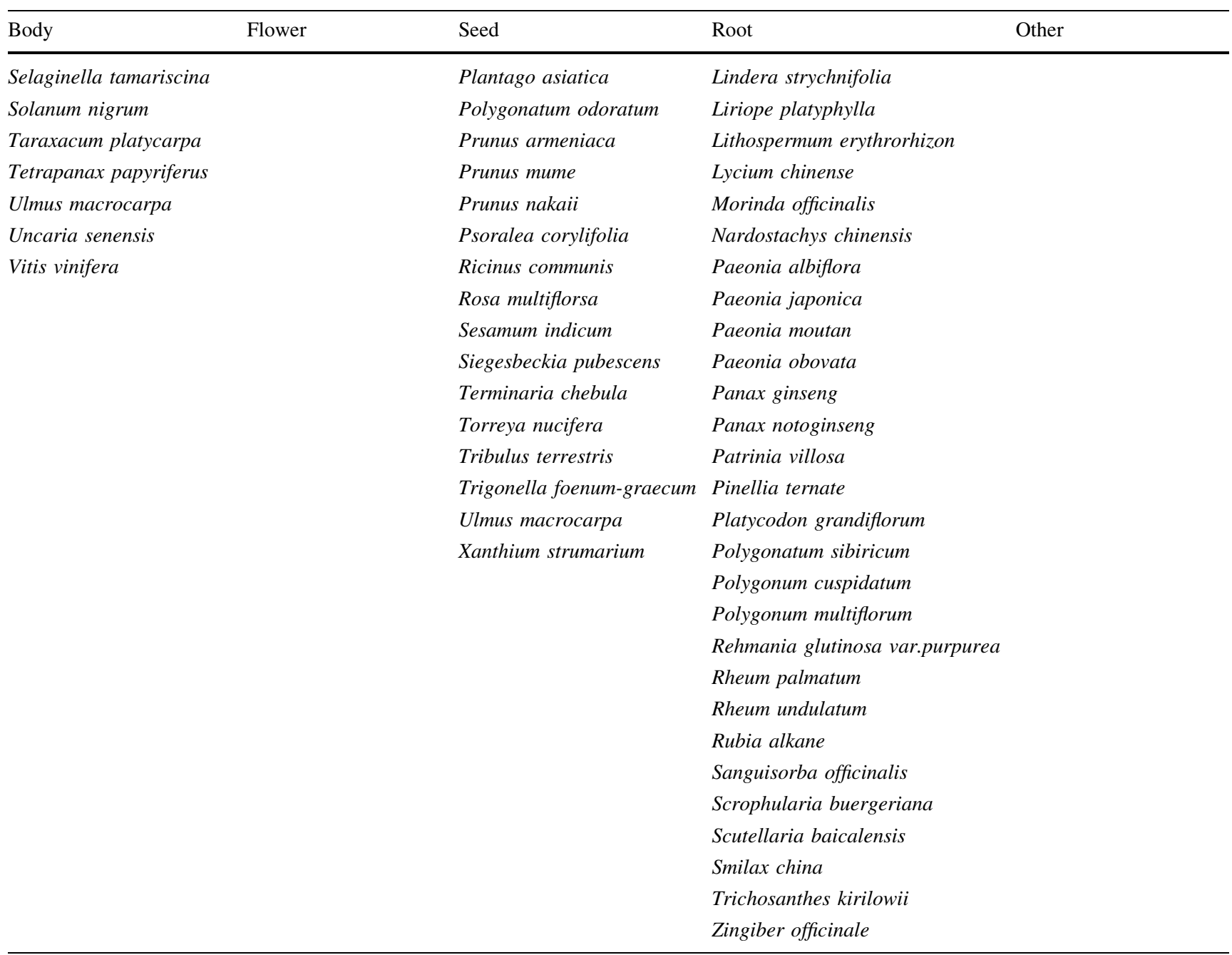
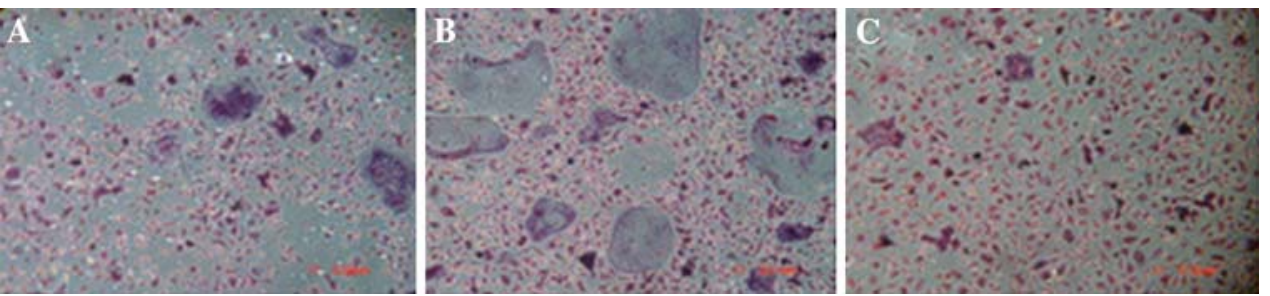

Fig. 1 The effects of the extracts in osteoclastogenesis of mouse macrophage by TRAP staining. a Control. b Lithospermum erythrorhizon stimulate osteoclastogenesis. c Shows suppression effects of Gleditsia japonica in osteoclastogenesis

of curry powder [19]. Daphne genkwa has an antitumor activity. The anti-tumor constituent, daphnodorin complex, was reported to have inhibitory effects on tumor growth and metastasis by protecting host immunocyte viability and proliferation potential, thus selectively inhibiting tumor cell proliferation [20]. Daphnane diterpene esters from flower buds induced apoptosis in human pro-myelocytic leukemia HL-60 cells. This esters were found to have suppressed the growth of Lewis lung carcinomas (LLC) inoculated into mice [21]. An anticoagulant purified from Taraxacum platycarpum has been used as an inflammatory agent to treat colitis and ulcer. In addition, this anticoagulant protein, when treated to the murine macrophage cell line RAW 264.7, induced expression of cyclooxygenase-2 (COX-2) and nitric oxide synthase, and production of antitumor necrosis factor- $\alpha$ [22]. The rhizome extract of Rheum undulatum was reported to have vasorelaxant, anti-allergic and anti-platelet aggregation activities [23, 24]. The 
Table 2 The positive effects of the crude compounds in osteoclastogenesis

\begin{tabular}{|c|c|c|c|}
\hline \multirow[t]{2}{*}{ Botanical name } & \multirow[t]{2}{*}{ Part used } & \multicolumn{2}{|l|}{ Effect } \\
\hline & & $0.1 \mathrm{mg} / \mathrm{ml}$ & $0.2 \mathrm{mg} / \mathrm{ml}$ \\
\hline Alpinia oxyphylla & Seed & Staining & Differentiation \\
\hline $\begin{array}{l}\text { Dryobalanops } \\
\text { aromatica }\end{array}$ & Resin & Differentiation & Differentiation \\
\hline Euphoria longana & Seed & Differentiation & Differentiation \\
\hline $\begin{array}{l}\text { Lithospermum } \\
\text { erythrorhizon }\end{array}$ & Root & Differentiation & Differentiation \\
\hline Plantago asiatica & Seed & Differentiation & Toxic \\
\hline $\begin{array}{l}\text { Polygonatum } \\
\text { odoratum }\end{array}$ & Seed & Differentiation & Differentiation \\
\hline Prunus тите & Seed & Differentiation & Differentiation \\
\hline Prunus nakaii & Seed & Differentiation & Differentiation \\
\hline $\begin{array}{l}\text { Sambucus williamsii } \\
\text { var.coreana }\end{array}$ & Body & Staining & Differentiation \\
\hline Zea mays & Flower & Differentiation & Suppression \\
\hline
\end{tabular}

Table 3 The negative effects of the crude compounds in osteoclastogenesis

\begin{tabular}{llll}
\hline Botanical name & Part used & Effect & \\
\cline { 3 - 4 } & & $0.1 \mathrm{mg} / \mathrm{ml}$ & $0.2 \mathrm{mg} / \mathrm{ml}$ \\
\hline Ailanthus altissima & Root & Suppression & Suppression \\
Citrus aurantium & Seed & Suppression & Toxic \\
Cnidium officinale & Root & Suppression & Toxic \\
Curcuma longa & Root & Suppression & Suppression \\
Daphne genkwa & Flower & Suppression & Suppression \\
Eugenia caryophyllata & Flower & Suppression & Suppression \\
Gleditsia japonica & Thorn & Staining & Suppression \\
Lindera strychnifolia & Root & Suppression & Toxic \\
Melandrium firmum & Body & Suppression & Toxic \\
Orostachys japonicus & Body & Suppression & Staining \\
Phaseolus angularis & Seed & Suppression & Soxic \\
Picrasma quassioides & Body & Staining & Suppression \\
Rheum undulatum & Root & Suppression & Toxic \\
Sanguisorba officinalis & Root & Staining & Suppression \\
Solanum nigrum & Body & Suppression & Suppression \\
Taraxacum platycarpa & Body & Suppression & Toxic \\
Trichosanthes kirilowii & Root & Suppression & Suppression \\
\hline
\end{tabular}

methanolic extract of the cortex of Eugenia caryophyllata exerted the COX-2 inhibitor activity in RAW264.7 cells [25].

Eugenol is a major component of essential oil isolated from the E. caryophyllata, which was reported as an anticancer agent [26]. The root tuber protein of Richosanthes kirilowii suppressed the HSV-1 infection by targeting the mitogen-activated protein kinase (MAPK) family pathway [27]. Water extract of the root of Lindera strychnifolia slowed down the progression of diabetic nephropathy in $\mathrm{db} / \mathrm{db}$ mice [28]. Citrus fruits were found to be a potentially important source of anti-inflammatory flavonoids in the human diet [29]. The peel of citrus fruits is a rich source of flavones. Nitric oxide (NO) has been implicated in a variety of pathophysiological conditions, including inflammation, carcinogenesis, and atherosclerosis [29]. The ethyl acetate soluble fraction of Cnidium officinale MAKINO inhibited neuronal cell death by reducing excessive NO production in LPS-treated rat hippocampal slice cultures and microglia cells [30]. The extract of Phaeseolus angularis (Adzuki bean) exhibited estrogenlike activities [31] but in different ways from Phaseolus lunatus $\mathrm{L}$.

Some medicinal plants showed stimulatory effects on osteoclast differentiation. The aqueous extract from the medicinal plant Dryobalanops aromatica specifically inhibited catecholamine secretion that is important in stressful states and emotional behavior [32]. The kaempferol derived from Polygonatum odoratum has been used for the treatment of chronic airway diseases [33]. Euphoria longana and Prunus mume fruit was reported to have an anti-cancer effects $[34,35]$. The naphthoquinone pigment, shikonin, isolated from Lithospermum erythrorhizon, has several therapeutic potential including anti-inflammatory and anti-tumor effects [36].

From these results, we found several compounds with stimulatory or inhibitory effects on osteoclastogenesis (Tables 2, 3). There were several medicinal plants that showed strong effects on osteoclast differentiation (Table 2), even though we could not find a relationship through these results in osteoclastogenesis. The next step will be a study with single compounds purified from 30 verified plants.

Acknowledgments This work was supported by the Project of Bio-Food Research from the Korea Science and Engineering Foundation (KOSEF) under the Ministry of Science and Technology in Korea, and also supported by grant No. R01-2006-000-10515-0 from the Basic Research Program of the Korea Science \& Engineering Foundation.

\section{References}

1. New SA, Robins SP, Campbell MK, Martin JC, Garton MJ, Bolton-Smith C, Grubb DA, Lee SJ, Reid DM (2000) Dietary influences on bone mass and bone metabolism: further evidence of a positive link between fruit and vegetable consumption and bone health? Am J Clin Nutr 71:142-151

2. Viereck V, Grundker C, Friess SC, Frosch KH, Raddatz D, Schoppet M, Nisslein T, Emons G, Hofbauer LC (2005) Isopropanolic extract of black cohosh stimulates osteoprotegerin production by human osteoblasts. J Bone Miner Res 20:2036-43 
3. Muhlbauer RC, Lozano A, Reinli A, Wetli H (2003) Various selected vegetables, fruits, mushrooms and red wine residue inhibit bone resorption in rats. J Nutr 133:3592-3597

4. Tucker KL, Hannan MT, Chen H, Cupples LA, Wilson PW, Kiel DP (1999) Potassium, magnesium, and fruit and vegetable intakes are associated with greater bone mineral density in elderly men and women. Am J Clin Nutr 69:727-736

5. Alekel DL, Germain AS, Peterson CT, Hanson KB, Stewart JW, Toda T (2000) Isoflavone-rich soy protein isolate attenuates bone loss in the lumbar spine of perimenopausal women. Am J Clin Nutr 72:844-852

6. Arjmandi BH, Alekel L, Hollis BW, Amin D, Stacewicz-Sapuntzakis M, Guo P, Kukreja SC (1996) Dietary soybean protein prevents bone loss in an ovariectomized rat model of osteoporosis. J Nutr 126:161-167

7. Breitman PL, Fonseca D, Cheung AM, Ward WE (2003) Isoflavones with supplemental calcium provide greater protection against the loss of bone mass and strength after ovariectomy compared to isoflavones alone. Bone 33:597-605

8. Potter SM, Baum JA, Teng H, Stillman RJ, Shay NF, Erdman JW $\mathrm{Jr}$ (1998) Soy protein and isoflavones: their effects on blood lipids and bone density in postmenopausal women. Am J Clin Nutr 68:1375S-1379S

9. Muhlbauer RC, Lozano A, Reinli A (2002) Onion and a mixture of vegetables, salads, and herbs affect bone resorption in the rat by a mechanism independent of their base excess. J Bone Miner Res 17:1230-1236

10. Muhlbauer RC, Lozano A, Palacio S, Reinli A, Felix R (2003) Common herbs, essential oils, and monoterpenes potently modulate bone metabolism. Bone 32:372-380

11. Chae HJ, Kang JS, Kim JH, Kim CW, Yoo SK, Shin TY, Choi B, Kim HM, Kim HR (2001) Antiosteoporotic activity of Dae-BoWon-Chun in ovariectomized rats. Phytother Res 15:53-57

12. Jin UH, Kim DI, Lee TK, Lee DN, Kim JK, Lee IS, Kim CH (2006) Herbal formulation, Yukmi-jihang-tang-Jahage, regulates bone resorption by inhibition of phosphorylation mediated by tyrosine kinase Src and cyclooxygenase expression. J Ethnopharmacol 106:333-343

13. Lee MS, Park KW, Park JS, Kim HJ, Moon SR (2005) Effects of nutritional supplement with herbal extract on bone mineral density and height in prepubescent children: a preliminary study. Phytother Res 19:810-811

14. Hur JM, Park JC (2006) Effects of the aerial parts of Orostachys japonicus and its bioactive component on hepatic alcoholmetabolizing enzyme system. J Med Food 9:336-341

15. Choi SY, Chung MJ, Seo WD, Shin JH, Shon MY, Sung NJ (2006) Inhibitory effects of Orostachys japonicus extracts on the formation of N-nitrosodimethylamine. J Agric Food Chem 54:6075-6078

16. Chan TY, Tomlinson B, Tse LK, Chan JC, Chan WW, Critchley JA (1994) Aconitine poisoning due to Chinese herbal medicines: a review. Vet Hum Toxicol 36:452-455

17. Zhao C, Li M, Luo Y, Wu W (2006) Isolation and structural characterization of an immunostimulating polysaccharide from fuzi, Aconitum carmichaeli. Carbohydr Res 341:485-491

18. De Feo V, Martino LD, Santoro A, Leone A, Pizza C, Franceschelli S, Pascale M (2005) Antiproliferative effects of tree-ofheaven (Ailanthus altissima Swingle). Phytother Res 19:226-230

19. Avwioro OG, Onwuka SK, Moody JO, Agbedahunsi JM, Oduola T, Ekpo OE, Oladele AA (2007) Curcuma longa extract as a histological dye for collagen fibres and red blood cells. J Anat 210:600-603

20. Zheng W, Gao X, Gu Q, Chen C, Wei Z, Shi F (2007) Antitumor activity of daphnodorins from Daphne genkwa roots. Int Immunopharmacol 7:128-134
21. Park BY, Min BS, Ahn KS, Kwon OK, Joung H, Bae KH, Lee HK, Oh SR (2006) Daphnane diterpene esters isolated from flower buds of Daphne genkwa induce apoptosis in human myelocytic HL-60 cells and suppress tumor growth in Lewis lung carcinoma (LLC)inoculated mouse model. J Ethnopharmacol 111:496-503

22. Yun SI, Cho HR, Choi HS (2002) Anticoagulant from Taraxacum platycarpum. Biosci Biotechnol Biochem 66:1859-1864

23. Ko SK, Lee SM, Whang WK (1999) Anti-platelet aggregation activity of stilbene derivatives from Rheum undulatum. Arch Pharm Res 22:401-403

24. Yoo MY, Oh KS, Lee JW, Seo HW, Yon GH, Kwon DY, Kim YS, Ryu SY, Lee BH (2007) Vasorelaxant effect of stilbenes from rhizome extract of rhubarb (Rheum undulatum) on the contractility of rat aorta. Phytother Res 21:186-189

25. Kim SS, Oh OJ, Min HY, Park EJ, Kim Y, Park HJ, Nam Han Y, Lee SK (2003) Eugenol suppresses cyclooxygenase-2 expression in lipopolysaccharide-stimulated mouse macrophage RAW264.7 cells. Life Sci 73:337-348

26. Yoo CB, Han KT, Cho KS, Ha J, Park HJ, Nam JH, Kil UH, Lee KT (2005) Eugenol isolated from the essential oil of Eugenia caryophyllata induces a reactive oxygen species-mediated apoptosis in HL-60 human promyelocytic leukemia cells. Cancer Lett 225:41-52

27. Huang H, Chan H, Wang YY, Ouyang DY, Zheng YT, Tam SC (2006) Trichosanthin suppresses the elevation of p38 MAPK, and Bcl-2 induced by HSV-1 infection in Vero cells. Life Sci 79:1287-1292

28. Ohno T, Takemura G, Murata I, Kagawa T, Akao S, Minatoguchi S, Fujiwara T, Fujiwara H (2005) Water extract of the root of Lindera strychnifolia slows down the progression of diabetic nephropathy in db/db mice. Life Sci 77:1391-1403

29. Choi SY, Ko HC, Ko SY, Hwang JH, Park JG, Kang SH, Han SH, Yun SH, Kim SJ (2007) Correlation between flavonoid content and the NO production inhibitory activity of peel extracts from various citrus fruits. Biol Pharm Bull 30:772-778

30. Kim JM, Son D, Lee P, Lee KJ, Kim H, Kim SY (2003) Ethyl acetate soluble fraction of Cnidium officinale MAKINO inhibits neuronal cell death by reduction of excessive nitric oxide production in lipopolysaccharide-treated rat hippocampal slice cultures and microglia cells. J Pharmacol Sci 92:74-78

31. Zhao QW, Huang X, Lou YJ, Weber N, Proksch P (2007) Effects of ethanol extracts from Adzuki bean (Phaseolus angularis Wight.) and Lima bean (Phaseolus lunatus L.) on estrogen and progesterone receptor phenotypes of MCF-7/BOS cells. Phytother Res 21:648-652

32. Oh KS, Park TJ, Choi BH, Lee DK, Lee TK, Kim KT (2000) Inhibition of nicotinic receptor-mediated catecholamine secretion by Dryobalanops aromatica in bovine adrenal chromaffin cells. Pharmacol Res 42:559-564

33. Lee CJ, Lee JH, Seok JH, Hur GM, Park Js J, Bae S, Lim JH, Park YC (2004) Effects of betaine, coumarin and flavonoids on mucin release from cultured hamster tracheal surface epithelial cells. Phytother Res 18:301-305

34. Jeong JT, Moon JH, Park KH, Shin CS (2006) Isolation and characterization of a new compound from Prunus mume fruit that inhibits cancer cells. J Agric Food Chem 54:2123-2128

35. Rangkadilok N, Worasuttayangkurn L, Bennett RN, Satayavivad J (2005) Identification and quantification of polyphenolic compounds in Longan (Euphoria longana Lam.) fruit. J Agric Food Chem 53:1387-1392

36. Chen X, Yang L, Oppenheim JJ, Howard MZ (2002) Cellular pharmacology studies of shikonin derivatives. Phytother Res 16:199-209 